\title{
Decrease in Stroke Diagnoses During the COVID-19 Pandemic: Where Did All Our Stroke Patients Go?
}

Adrienne Nicole Dula ${ }^{1,2}, \mathrm{PhD}, \mathrm{MSc}$; Gretchel Gealogo Brown ${ }^{3}, \mathrm{PhD}, \mathrm{RN}, \mathrm{CMSRN}$; Aarushi Aggarwal ${ }^{4}$, BS; Kal L Clark ${ }^{5}, \mathrm{MD}$

\footnotetext{
${ }^{1}$ Department of Neurology, Dell Medical School, The University of Texas at Austin, Austin, TX, United States

${ }^{2}$ Department of Diagnostic Medicine, Dell Medical School, The University of Texas at Austin, Austin, TX, United States

${ }^{3}$ School of Nursing, University of Texas Health Science Center at San Antonio, San Antonio, TX, United States

${ }^{4}$ Long School of Medicine, University of Texas Health, San Antonio, TX, United States

${ }^{5}$ Department of Radiology, University of Texas Health Science Center at San Antonio, San Antonio, TX, United States
}

\section{Corresponding Author:}

Adrienne Nicole Dula, $\mathrm{PhD}$, MSc

Department of Neurology

Dell Medical School

The University of Texas at Austin

1601 Trinity Street Building B

Austin, TX, 78712

United States

Phone: 15124955922

Email: adrienne.dula@austin.utexas.edu

\section{Abstract}

Despite the evidence suggesting a high rate of cerebrovascular complications in patients with SARS-CoV-2, reports have indicated decreasing rates of new ischemic stroke diagnoses during the COVID-19 pandemic. The observed decrease in emergency department (ED) visits is unsurprising during this major crisis, as patients are likely to prioritize avoiding exposure to SARS-CoV-2 over addressing what they may perceive as mild symptoms of headache, lethargy, difficulty speaking, and numbness. In the central and south Texas regions where we practice, we suspect that patient admission, treatment, and discharge volumes for acute stroke treatment have decreased significantly since COVID-19-related shelter-at-home orders were issued. Symptoms of stroke are frequently noticed by a family member, friend, or community member before they are recognized by the patients themselves, and these symptoms may be going unnoticed due to limited face-to-face encounters. This possibility emphasizes the importance of patient education regarding stroke warning signs and symptoms during the current period of isolation and social-distancing. The south Texas population, already saddled with above-average rates of cardiovascular and cerebrovascular disease, has a higher stroke mortality rate compared to Texas and U.S. averages; however, the number of patients presenting to EDs with acute ischemic stroke diagnoses is lower than average. In our viewpoint, we aim to present the relative literature to date and outline our ongoing analyses of the highly affected and diverse stroke populations in San Antonio and Austin, Texas, to answer a simple question: where did all our stroke patients go?

(JMIR Aging 2020;3(2):e21608) doi: 10.2196/21608

\section{KEYWORDS}

stroke; ischemic stroke; COVID-19; SARS-CoV-2; emergency medicine; cerebrovascular

\section{Introduction}

In the midst of a pandemic, the advice from medical professionals to "stay home, save lives" may be preventing patients from seeking medical care when symptoms of stroke arise due to fear of contracting COVID-19. Anecdotal reports across the United States are highlighting missed care during the current COVID-19 pandemic [1-3]; the World Health
Organization has acknowledged a marked decrease in stroke presentations and a widespread impact of the pandemic on stroke care [4]. Local and state shelter-at-home orders have imposed strict limitations on clinic and hospital access, restrictions on nonessential travel, social distancing policies, and mandated isolation of populations that are especially vulnerable to COVID-19 infection, such as older and immunocompromised people. In our persistent efforts to educate communities about 
COVID-19 infection risk, we may be undermining potentially lifesaving public health education campaigns for emergent medical conditions such as heart attack or stroke. The aim of this viewpoint is to present the relative literature to date and outline ongoing analyses of the highly affected and diverse stroke populations in San Antonio and Austin, Texas.

In the central and south Texas regions where we practice, we suspect that patient admission, treatment, and discharge volumes for acute stroke treatment have decreased significantly since COVID-19-related shelter-at-home orders were issued. This decrease appears to mirror sharp downward trends in emergency department (ED) visits since Texas municipalities began enforcing local guidelines for social distancing. This is especially concerning for the San Antonio metropolitan statistical area. Our population is already saddled with above-average rates of cardiovascular and cerebrovascular disease and has a higher stroke mortality rate compared to the Texas and US averages [5-7]. Hesitation to leave shelter-in-place due to COVID-19 and present to the ED could result in worse outcomes, particularly for ischemic stroke $[8,9]$. To put it simply: where did all our stroke patients go?

Answering this question presents a unique opportunity to maximize the information-laden infrastructure already in place for tracking acute stroke care: "Get With The Guidelines" (GWTG) stroke registry of the American Heart Association/American Stroke Association (AHA/ASA). Required for Joint Commission and Det Norske Veritas Germanischer Lloyd (DNV-GL) stroke center certification, GWTG registries provide a mechanism for hospitals to track the efficiency and effectiveness of their acute stroke care for continuous program evaluation and quality improvement. It should be noted that in April 2020, a COVID-19 item for tracking testing and outcomes was added to the registry case report form.

\section{Increasing Stress on the Hospital System}

Without the typical rigorous process of development, refinement, and peer review of national recommendations, on March 20, 2020, the AHA/ASA released a broad but flexible policy statement that reflects both the commonality of the pandemic across the United States and the individual variability at local sites [10]. The report was issued as a temporary statement and interim stopgap opinion pending a more thorough and contemplative process. Obstacles to acute stroke care were cited, including shortages in personal protective equipment (PPE), hospital personnel, and hospital beds.

Initial reports from other countries have already highlighted the stress of COVID-19 on their intensive care units (ICUs) and resources [11-13]. A recent case series of critically ill patients with COVID-19 in Seattle, Washington, reported a median ICU stay of 14 days and a median duration of mechanical ventilation of 10 days [14]. With EDs and ICU triaging and caring for increasing numbers of patients with COVID-19, the COVID-19 pandemic will have a tremendous impact on available resources for the triage and treatment of acute ischemic stroke.
Many patients with stroke often fail to recognize mild symptoms such as visual field disturbance, facial droop, or neglected extremities. Symptoms of stroke are frequently noticed by a family member, friend, or community member before they are recognized by the patients themselves, which emphasizes the importance of patient education regarding warning signs and symptoms of stroke during the current exigent period of isolation and social distancing.

\section{Suggested Guidelines for Stroke Care}

Current practice for the management of acute ischemic stroke will require modification, and although it has been recommended that guidelines should be relaxed while maintaining a high standard quality of care [15], most published guidelines or recommendations (Table S1, Multimedia Appendix 1) state that established guidelines should be followed [10,12,14,16-22]. Others have published suggestions for acute ischemic stroke care with modifications to standard treatment guidelines [23-25]. There is an overall collective aim to avoid contributing to the rapid spread of COVID-19 while conserving what are likely to be very limited resources (including personnel, ICU and hospital beds, and physicians) while providing acute ischemic stroke care $[15,23]$. The concept of a "protected code stroke" during a pandemic, as in the case of COVID-19, was introduced for Canadian practice by Khosravani et al [20]; this concept provides a framework for key considerations, including screening, PPE, and crisis resource management.

Recommendations covering the areas of education, screening, imaging, treatment, transfer, discharge, and follow-up procedures have been published. A number of publications have highlighted the importance of improving educational outreach for health professionals and the public, particularly those at high risk of stroke, to recognize stroke and call emergency medical services (EMS), thus avoiding significant delays and worse outcomes $[12,13,19,26,27]$. To minimize risk of infection, many guidelines suggest screening for COVID-19 symptoms and exposure as soon as possible, including remotely or by EMS, and communicating the results to the stroke team $[14,16,18,20,22,25]$.

Recommended strategies regarding imaging include establishing a COVID-specific scanner [16,17] and performing magnetic resonance imaging (MRI) first so that patients do not require multiple scanning sessions [25]. Identification of transient ischemic attacks (TIAs) and mild strokes without deficits and no indication for emergent treatment could be addressed with remote management [14,25,26]. While most published recommendations indicate that established guidelines should be followed regarding treatment, French interventionalists suggest withholding treatment from patients in the ICU who test positive for COVID-19 [22] and others suggest remote review of treatment eligibility, including functional exams $[10,25]$. In specific reference to endovascular therapy (EVT) procedures, some guidelines recommend early intubation of patients prior to initiation $[20,21,28]$ or require confirmed COVID-19-negative status prior to the procedure [24]. Rapid discharge of patients who can be managed at home $[12,14,17,25]$ and remote follow-up consultations $[12,14,17,19,20,22,27]$ are 
also mentioned as strategies. Finally, early recognition of the need for transport to a designated stroke center can reduce interfacility transfers, effectuating a reduction in potential infectious exposure [26].

\section{Decrease in Ischemic Stroke Patients}

As people continue to adjust to social distancing, a shift in the epidemiology of stroke and other medical conditions will most likely be observed, as is being seen in myocardial infarction [29] and in other countries [30-37] in the context of acute ischemic stroke. Although there is evidence to suggest a high rate of cerebrovascular complications in patients with SARS-CoV-2 infection [38-43], anecdotal reports indicate a falling rate of new ischemic stroke admissions [30-32,34,37,44-48], stroke code activations [30,36,49-53], imaging numbers $[44,45]$, and diagnoses [45].

This decrease in patient load is hypothesized by some to be driven by fewer patients presenting to the ED [54,55]. Studies have also noted a decrease in admissions of TIAs [31] and a decrease in patients presenting with mild symptoms, as demonstrated by higher National Institutes of Health Stroke Scale (NIHSS) scores [32,34,50] and decreased proportion of large vessel occlusions (LVOs) [45]. These data may indicate that a smaller proportion of patients are seeking services for mild symptoms [45].

Additionally, decreases in acute ischemic stroke treatment numbers have been noted for both thrombolysis [46,53,56,57] and EVT [30,33,47,53,56], with an excellent meta-analysis presented by July et al [53], including data from nine studies [30,56,58-64]. Details of each of these studies, as well as other related studies $[65,66]$, can be found in Table S2 (Multimedia Appendix 1). Interestingly, despite noted decreases in EVT numbers overall, some studies have shown that the proportion of patients receiving EVT increased [48,53], possibly due to an increase in the number of late presenters $[34,58]$ or an increase in the number of patients eligible for EVT. Upon examination, the majority of studies reported no change in process times, such as time last known well (TLKW) to arrival $[45,47,49,51]$, TLKW to imaging [45], TLKW to thrombolysis [45,48,49,51], and length of hospital stay [47]. However, other studies reported an increase in the process time from TLKW to EVT procedure [33] or no change in the length of hospital stay [47].

Of particular interest for our planned analyses is the report by Kansagra et al [44] quantifying the stroke imaging load for each state via the RAPID software database (iSchemaView Inc). Texas-specific data show that prepandemic (February 1 through February 29,2020), Texas had a mean of 63.3 patients per day (95\% CI 60.2-66.5), and in the early pandemic (March 26 through April 8, 2020), the mean was 43.1 patients per day (95\% CI 40.1-46.2), representing a change of $-31.8 \%$ (95\% CI $-25.8 \%$ to $-37.6 \%$ ). There were no significant differences with respect to age, sex, race, vascular risk factors, or severity. Upon examining stroke type, the proportion of new LVOs nearly doubled in the COVID-19 period $(n=20,38 \%$, vs $n=59,21 \%$, $P=.01)$ relative to the pre-pandemic timeframe. Despite differences in proportions, the mean number of LVO patients in the COVID-19 period (0.43 per day) did not differ significantly ( $P=.61)$ from that pre-COVID-19 (0.39 per day). Finally, evaluation of time revealed that patients treated during the COVID-19 period had no significant delay from TLKW to arrival or from arrival to imaging or treatment [45]. These results further support that the driving factor for the decrease in stroke volume is that patients experiencing mild strokes are not seeking acute care.

Accurately identifying the root cause of the decrease in stroke volume is challenging due to a combination of socioeconomic and pathophysiologic factors. Widely observed decreases in acute ischemic stroke presentation are potentially influenced by the risk profile of the population: during the COVID-19 era, patients with risk factors such as hypertension, hyperlipidemia, coronary artery disease, lack of insurance, or urban location increased their proportion of the stroke cohort [52]. Population health strategies to reduce COVID-19 may also lower infection rates with vasculotropic viruses and allergens that can trigger atherosclerosis and plaque rupture, which may result in neurovascular and cardiovascular morbidity $[67,68]$.

\section{Disparities}

There is increasing evidence that some racial and ethnic minority groups are being disproportionately affected by COVID-19 [69-73]. Hypothesized mechanisms include an elevated severity of response to SARS-CoV-2 and increased socioeconomic risk [74]. Persons who are African American, Black, or Latino are contracting SARS-CoV-2 at higher rates and experiencing higher mortality [75-78], and comorbidities may explain these differences [74]. Due to this increased risk, Black and Hispanic or Latino patients, particularly those without health insurance [52], may avoid medical care. Observations from a telestroke registry in North Carolina reported that a lower percentage of Black patients presented during the pandemic (13.9\% versus $29 \%$ before the pandemic, $P<.001)$.

Racial and ethnic minority groups who are more likely to rely on the ED for primary care may avoid seeking primary care because of concerns about the infection risk in the ED. The avoidance of primary care for chronic disease management can subsequently manifest in an increase in emergent hospitalization for stroke. A statistically significant increase in the proportion of Black and Hispanic patients presenting with strokes was noted in California, Pacific hospitals, Western hospitals, and all hospitals in the United States during various months studied, comparing 2020 to 2019 [79]. It is not clear what proportion of patients with severe strokes are foregoing medical care or are otherwise underdiagnosed.

Further work is needed to explore the complex interplay of socioeconomic factors and pathophysiologic mechanisms and the impact this interplay has on acute stroke presentation in minority populations. Until this work is performed, it may be difficult to effectively target population health resources and address the disparity.

\section{Planned Analyses}

Unfortunately, when patients misinterpret stroke symptoms or assume that the symptoms will resolve without intervention, 
they are delaying clinical care. Without emergency medical attention, strokes can cause devastating and irreversible damage, with the extent being largely dependent on the timing of the intervention. Furthermore, infection prevention protocols may complicate discussions between the patient and emergency responders as well as subsequent management and treatment. Hospital and EMS procedures are consistently adapting to the situation as reports from around the world detail experiences and provide data on which to base acute stroke care decisions during this pandemic.

It is necessary to comprehensively evaluate the impact of current stay-at-home orders and patient fears on incidence and severity of ischemic stroke. Metrics can be extracted from the GWTG stroke registry data along with related neuroimaging exams from hospitals in Texas metropolitan areas (San Antonio and Austin). Unlike San Antonio, Austin and its surrounding counties have lower cardiovascular and cerebrovascular disease rates and stroke mortality rates compared to Texas and US averages due to a combination of socioeconomic status, public health, infrastructure, and demographic differences. Thus, Austin will serve as a de facto control group. For this study, which has been approved by the University of Texas Health Science Center and The University of Texas at Austin Institutional Review Boards, data from San Antonio and Austin will be divided into three cohorts:

1. Prior to the COVID-19 pandemic: Records of stroke patients with admission dates 15 months prior and up to March 31, 2020, when the governor of Texas issued Executive Order No. GA-14, which effectively limited out-of-household social gatherings and in-person contact to only those necessary for providing or obtaining essential services.

2. Stay-at-home order in effect: Records of stroke patients with admission dates from April 1 to April 30, 2020, while the above executive order was in effect.

3. Stay-at-home order rescinded: Records of stroke patients with admission dates up to 15 months after May 1, 2020, when the above executive order was discontinued.

A fourth cohort of stroke patients will be created if stay-at-home orders are reinstated during the 15-month period after May 1, 2020. We will test the hypothesis that the overall stroke presentation rate (including positive and negative cases), absolute numbers of stroke diagnoses, and stroke interventions decline during COVID-19 stay-at-home orders are in effect compared to control time epochs. We plan to analyze admission, treatment, and discharge variables within and between time cohorts and metropolitan areas, and when available, we will analyze data on COVID-19 testing and outcomes that occurred during stroke treatment. San Antonio and Austin-area GWTG data to be extracted for the study data set will include patient demographics (age, gender, race/ethnicity)

- Arrival and admission data (locations where stroke symptoms were discovered, mode of arrival to ED, vital signs, laboratory test results, height/weight/BMI, inpatient unit assigned for stroke care)

- Medical history (pertinent medical history and medications)

- Diagnosis and evaluation (initial NIHSS score and exam findings)
- Symptom timeline (date/time of last known well, date/time of symptom discovery)

- Brain imaging (imaging modality, initiation date/time, interpretation of findings)

- Acute therapeutic interventions (intravenous thrombolytic therapy, EVT, related complications)

- Other in-hospital treatment and screening (interventions for venous thromboembolism, anticoagulation, bacterial/viral infection)

- Discharge status (modified Rankin Scale score at discharge, ambulatory status)

- Discharge treatment (antithrombotic therapy, antihypertensive therapy, statin therapy, antihyperglycemic therapy, patient education, follow-up diagnostic tests and procedures)

We anticipate a sample of $n=1000$ GWTG records from 11 hospitals (of which 4 are comprehensive stroke centers) in the San Antonio and Austin metropolitan statistical areas for the study data set. Kruskal-Wallis and Levene tests will be used to assess differences in categorical and continuous GWTG variables between and within time periods and metropolitan area cohorts, and segmented regression will be used to assess whether stroke presentation, interventions, and outcomes are more or less severe over the pre-, during, and post-COVID-19 stay-at-home order time periods.

\section{Conclusions}

Fear and heightened caution are not the only factors that contribute to reduced ED visits during burdensome times. Looking retrospectively at ED trends during natural disasters offers another perspective on decreasing ED visits. A study that analyzed the effects of Hurricane Sandy, a hurricane that struck the east coast of the United States in 2012, on cardiovascular events found that in the days following the disaster, there were increases in incidence and mortality of myocardial infarction and in stroke incidence [80]. The authors referenced a multitude of studies documenting increased incidence of cerebrovascular events during natural disasters or severe weather events. Although the underlying etiologies of that increase have not been proven, possibilities include emotional stress related to increased platelet activation [81] and delayed treatment due to disrupted transportation networks, health care capacity, and supply chains. In terms of cerebrovascular events, the COVID-19 crisis may represent the worst-case scenario: fear of nosocomial infection causing health care avoidance when, for physiological and/or psychological reasons, the population is most vulnerable.

An observed decrease in ED visits should come as no shock during times of major crises, as patients prioritize safety from the "current danger" over what they may perceive as mild symptoms of chest pain, abdominal pain, weakness, etc., that they hope will "resolve on their own." This trend of decreased ED use was previously observed during the 2003 severe acute respiratory disorder (SARS) outbreak, in which ED visits at the height of the epidemic in Taipei showed a $51.6 \%$ decline, with a mean of 115.4 visits (SD 16.7) compared to the previous year (mean 238.3 visits, SD 33.4, 95\% CI of the mean difference 
109.4-136.3; $P<.01$ ) [82]. Further analysis showed persistence of this pattern for the 2015 Middle East respiratory syndrome (MERS) outbreak in South Korea as well. The age-standardized prevalence ratio for ED visits per 100,000 people in June 2015 decreased to 0.72 , with June 2014 and 2016 as references. The mean age-standardized prevalence for June 2015 was 708.48 (95\% CI 706.15-710.82), and the mean number of ED visits for ischemic stroke in 2015 (5406) decreased by 33.1\% in comparison to that of the year before the outbreak (6185 in June
2014) and the year after the outbreak (6776 in June 2016) [83]. Subgroup analyses in that study identified a concerning phenomenon: the volumes of high-acuity diseases such as myocardial infarction and ischemic stroke demonstrated a significant decrease in ED visits (14.0\% and 16.6\% decreases, respectively). These historical trends, including those observed for the current COVID-19 pandemic, raise the hypothesis that fear of nosocomial infection transmission can have deleterious population health consequences.

\section{Acknowledgments}

This research was made possible by funding made available by the Texas Legislature to the Lone Star Stroke Clinical Trial Network. Its contents are solely the responsibility of the authors and do not necessarily represent the official views of the Government of the United States or the State of Texas. There are no financial disclosures to report.

\section{Conflicts of Interest}

None declared.

\section{Multimedia Appendix 1}

Suggested guidelines and protocols for management of acute stroke and key studies evaluating acute stroke trends during the COVID-19 pandemic.

[DOCX File, 47 KB-Multimedia Appendix 1]

\section{References}

1. Bernstein L, Sellers S. Patients with heart attacks, strokes and even appendicitis vanish from hospitals. The Washington Post. 2020 Apr 19. URL: https://www.washingtonpost.com/health/ patients-with-heart-attacks-strokes-and-even-appendicitis-vanish-from-hospitals/2020/04/19/ 9ca3ef24-7eb4-11ea-9040-68981f488eed_story.html [accessed 2020-10-19]

2. Grady D. The Pandemic's Hidden Victims: Sick or Dying, but Not From the Virus. The New York Times. 2020 Apr 20. URL: https://www.nytimes.com/2020/04/20/health/treatment-delays-coronavirus.html [accessed 2020-10-19]

3. Poll: Nearly Half of the Public Say They or a Family Member Skipped or Delayed Care Due to Coronavirus, But Most Plan to Get Care in the Coming Months. Kaiser Family Foundation. 2020 May 27. URL: https://www.kff.org/ coronavirus-covid-19/press-release/poll-nearly-half-of-the-public-say-they-or-a-family-member-skipped-or-delayed-caredue-to-coronavirus-but-most-plan-to-get-care-in-the-coming-months/ [accessed 2020-10-19]

4. Markus HS, Brainin M. COVID-19 and stroke-A global World Stroke Organization perspective. Int J Stroke 2020 Jun;15(4):361-364. [doi: 10.1177/1747493020923472] [Medline: $\underline{32310017]}$

5. Benjamin EJ, Blaha MJ, Chiuve SE, Cushman M, Das SR, Deo R, American Heart Association Statistics CommitteeStroke Statistics Subcommittee. Heart Disease and Stroke Statistics-2017 Update: A Report From the American Heart Association. Circulation 2017 Mar 07;135(10):e146-e603 [FREE Full text] [doi: 10.1161/CIR.0000000000000485] [Medline: 28122885]

6. Virani SS, Alonso A, Benjamin EJ, Bittencourt MS, Callaway CW, Carson AP, American Heart Association Council on EpidemiologyPrevention Statistics CommitteeStroke Statistics Subcommittee. Heart Disease and Stroke Statistics-2020 Update: A Report From the American Heart Association. Circulation 2020 Mar 03;141(9):e139-e596. [doi: 10.1161/CIR.0000000000000757] [Medline: 31992061]

7. Yang Q, Tong X, Schieb L, Vaughan A, Gillespie C, Wiltz JL, et al. Vital Signs: Recent Trends in Stroke Death Rates United States, 2000-2015. MMWR Morb Mortal Wkly Rep 2017 Sep 08;66(35):933-939 [FREE Full text] [doi: 10.15585/mmwr.mm6635e1] [Medline: 28880858]

8. Emberson J, Lees KR, Lyden P, Blackwell L, Albers G, Bluhmki E, Stroke Thrombolysis Trialists' Collaborative Group. Effect of treatment delay, age, and stroke severity on the effects of intravenous thrombolysis with alteplase for acute ischaemic stroke: a meta-analysis of individual patient data from randomised trials. Lancet 2014 Nov 29;384(9958):1929-1935 [FREE Full text] [doi: 10.1016/S0140-6736(14)60584-5] [Medline: 25106063]

9. Nogueira RG, Jadhav AP, Haussen DC, Bonafe A, Budzik RF, Bhuva P, DAWN Trial Investigators. Thrombectomy 6 to 24 Hours after Stroke with a Mismatch between Deficit and Infarct. N Engl J Med 2018 Jan 04;378(1):11-21. [doi: 10.1056/NEJMoa1706442] [Medline: 29129157]

10. AHA/ASA Stroke Council Leadership. Temporary Emergency Guidance to US Stroke Centers During the Coronavirus Disease 2019 (COVID-19) Pandemic: On Behalf of the American Heart Association/American Stroke Association Stroke Council Leadership. Stroke 2020 Jun;51(6):1910-1912. [doi: 10.1161/STROKEAHA.120.030023] [Medline: 32233972] 
11. Remuzzi A, Remuzzi G. COVID-19 and Italy: what next? Lancet 2020 Apr 11;395(10231):1225-1228 [FREE Full text] [doi: 10.1016/S0140-6736(20)30627-9] [Medline: $\underline{\text { 32178769] }}$

12. Rodríguez-Pardo J, Fuentes B, Alonso de Leciñana M, Campollo J, Calleja Castaño P, Carneado Ruiz J, en nombre del Grupo Multidisciplinar del Plan Ictus Madrid. Acute stroke care during the COVID-19 pandemic. Ictus Madrid Program recommendations. Neurologia 2020 May;35(4):258-263 [FREE Full text] [doi: 10.1016/j.nrl.2020.04.008] [Medline: 32364127]

13. Zhao J, Rudd A, Liu R. Challenges and Potential Solutions of Stroke Care During the Coronavirus Disease 2019 (COVID-19) Outbreak. Stroke 2020 May;51(5):1356-1357 [FREE Full text] [doi: 10.1161/STROKEAHA.120.029701] [Medline: 32228369]

14. Bhatraju PK, Ghassemieh BJ, Nichols M, Kim R, Jerome KR, Nalla AK, et al. Covid-19 in Critically Ill Patients in the Seattle Region - Case Series. N Engl J Med 2020 Mar 30 [FREE Full text] [doi: 10.1056/NEJMoa2004500] [Medline: $\underline{32227758]}$

15. Dafer RM, Osteraas ND, Biller J. Acute Stroke Care in the Coronavirus Disease 2019 Pandemic. J Stroke Cerebrovasc Dis 2020 Jul;29(7):104881 [FREE Full text] [doi: 10.1016/j.jstrokecerebrovasdis.2020.104881] [Medline: $\underline{32334918]}$

16. Baracchini C, Pieroni A, Viaro F, Cianci V, Cattelan AM, Tiberio I, et al. Acute stroke management pathway during Coronavirus-19 pandemic. Neurol Sci 2020 May;41(5):1003-1005 [FREE Full text] [doi: 10.1007/s10072-020-04375-9] [Medline: $\underline{\text { 32270359] }}$

17. Bhatia R, Sylaja PN, Srivastava MVP, Khurana D, Pandian JD, Suri V, et al. Consensus Statement - Suggested Recommendations for Acute Stroke Management during the COVID-19 Pandemic: Expert Group on Behalf of the Indian Stroke Association. Ann Indian Acad Neurol 2020 Apr;23(Suppl 1):S15-S23 [FREE Full text] [doi: 10.4103/aian.AIAN 302 20] [Medline: 32419749]

18. Meyer D, Meyer BC, Rapp KS, Modir R, Agrawal K, Hailey L, et al. A Stroke Care Model at an Academic, Comprehensive Stroke Center During the 2020 COVID-19 Pandemic. J Stroke Cerebrovasc Dis 2020 Aug;29(8):104927 [FREE Full text] [doi: 10.1016/j.jstrokecerebrovasdis.2020.104927] [Medline: 32434728]

19. Wan Asyraf WZ, Ah Khan YK, Chung LW, Kee HF, Irene L, Ang CL, et al. Malaysia Stroke Council guide on acute stroke care service during COVID-19 Pandemic. Med J Malaysia 2020 May;75(3):311-313 [FREE Full text] [Medline: 32467554]

20. Khosravani H, Rajendram P, Notario L, Chapman MG, Menon BK. Protected Code Stroke: Hyperacute Stroke Management During the Coronavirus Disease 2019 (COVID-19) Pandemic. Stroke 2020 Jun;51(6):1891-1895 [FREE Full text] [doi:

10.1161/STROKEAHA.120.029838] [Medline: 32233980]

21. Fraser JF, Arthur AS, Chen M, Levitt M, Mocco J, Albuquerque FC, et al. Society of NeuroInterventional Surgery recommendations for the care of emergent neurointerventional patients in the setting of COVID-19. J Neurointerv Surg 2020 Jun;12(6):539-541. [doi: 10.1136/neurintsurg-2020-016098] [Medline: $\underline{\text { 32295835] }}$

22. Préconisations de la SFNV et de la SFNR pour la prise en charge des patients victimes d?AVC en période d?épidémie à coronavirus COVID-19. Société Française Neuro-Vasculaire and Société Française de Neuroradiologie. 2020. URL: https:/ /docs.wixstatic.com/ugd/47ae18 e5e804cc2fe24c3da994e543e7618e00.pdf [accessed 2020-10-19]

23. Qureshi AI, Abd-Allah F, Al-Senani F, Aytac E, Borhani-Haghighi A, Ciccone A, et al. Management of acute ischemic stroke in patients with COVID-19 infection: Report of an international panel. Int J Stroke 2020 Jul;15(5):540-554. [doi: 10.1177/1747493020923234] [Medline: 32362244]

24. Pezzella F, Caso V, Causin F. Documento ISO-SIN-SNO-SICVE- AINRANEU- ALICe Italia Odv: Ictus- COVID-19. Italian Stroke Organization. URL: http://www.sicve.it/wp-content/uploads/2020/04/Documento-Intersocietario-Ictus-Covid. pdf [accessed 2020-09-15]

25. Clinical guide for the management of stroke patients during the coronavirus pandemic. Royal College of Physicians. 2020 03. URL: https://www.corhealthontario.ca/C033-Specialty-guide-Stroke-and-coronavirus-v1-24-March-2020.pdf [accessed 2020-10-19]

26. Alzahrani SS, Aleisa FK, Alghalbi JA, Taher NY, Alqahtani SA, Majrashi NA, et al. Stroke management pathway during COVID-19 pandemic scientific statement by the Saudi Stroke Society. Neurosciences (Riyadh) 2020 Jul;25(3):226-229. [doi: 10.17712/nsj.2020.3.20200079] [Medline: 32683407]

27. Wira CR, Goyal M, Southerland AM, Sheth KN, McNair ND, Khosravani H, AHA/ASA Stroke Council Science Subcommittees: Emergency Neurovascular Care (ENCC), Telestroke and the Neurovascular Intervention Committees; on behalf of the Stroke Nursing Science Subcommittee of the AHA/ASA Cardiovascular and Stroke Nursing Council. Pandemic Guidance for Stroke Centers Aiding COVID-19 Treatment Teams. Stroke 2020 Aug;51(8):2587-2592 [FREE Full text] [doi: 10.1161/STROKEAHA.120.030749] [Medline: 32716826]

28. Qureshi AI, Abd-Allah F, Al-Senani F, Aytac E, Borhani-Haghighi A, Ciccone A, et al. Management of acute ischemic stroke in patients with COVID-19 infection: Insights from an international panel. Am J Emerg Med 2020 Jul;38(7):1548.e5-1548.e7 [FREE Full text] [doi: 10.1016/j.ajem.2020.05.018] [Medline: 32444298]

29. Garcia S, Albaghdadi MS, Meraj PM, Schmidt C, Garberich R, Jaffer FA, et al. Reduction in ST-Segment Elevation Cardiac Catheterization Laboratory Activations in the United States During COVID-19 Pandemic. J Am Coll Cardiol 2020 Jun 09;75(22):2871-2872 [FREE Full text] [doi: 10.1016/j.jacc.2020.04.011] [Medline: 32283124] 
30. Rudilosso S, Laredo C, Vera V, Vargas M, Renú A, Llull L, et al. Acute Stroke Care Is at Risk in the Era of COVID-19: Experience at a Comprehensive Stroke Center in Barcelona. Stroke 2020 Jul;51(7):1991-1995 [FREE Full text] [doi: 10.1161/STROKEAHA.120.030329] [Medline: 32438895]

31. Hoyer C, Ebert A, Huttner HB, Puetz V, Kallmünzer B, Barlinn K, et al. Acute Stroke in Times of the COVID-19 Pandemic: A Multicenter Study. Stroke 2020 Jun 09;51(7):2224-2227. [doi: 10.1161/STROKEAHA.120.030395] [Medline: 32516064]

32. Diegoli H, Magalhães PSC, Martins SCO, Moro CHC, França PHC, Safanelli J, et al. Decrease in Hospital Admissions for Transient Ischemic Attack, Mild, and Moderate Stroke During the COVID-19 Era. Stroke 2020 Aug;51(8):2315-2321 [FREE Full text] [doi: 10.1161/STROKEAHA.120.030481] [Medline: 32530738]

33. Hajdu SD, Pittet V, Puccinelli F, Ben Hassen W, Ben Maacha M, Blanc R, et al. Acute Stroke Management During the COVID-19 Pandemic: Does Confinement Impact Eligibility for Endovascular Therapy? Stroke 2020 Jul 01;51(8):2593-2596 [FREE Full text] [doi: 10.1161/STROKEAHA.120.030794] [Medline: 32716828]

34. Kristoffersen ES, Jahr SH, Thommessen B, Rønning OM. Effect of COVID-19 pandemic on stroke admission rates in a Norwegian population. Acta Neurol Scand 2020 Jul 03 [FREE Full text] [doi: 10.1111/ane.13307] [Medline: 32620027]

35. Ntaios G, Michel P, Georgiopoulos G, Guo Y, Li W, Xiong J, et al. Characteristics and Outcomes in Patients With COVID-19 and Acute Ischemic Stroke: The Global COVID-19 Stroke Registry. Stroke 2020 Sep;51(9):e254-e258 [FREE Full text] [doi: 10.1161/STROKEAHA.120.031208] [Medline: 32787707]

36. Paliwal PR, Tan BYQ, Leow AST, Sibi S, Chor DWP, Chin AXY, et al. Impact of the COVID-19 pandemic on hyperacute stroke treatment: experience from a comprehensive stroke centre in Singapore. J Thromb Thrombolysis 2020 Oct;50(3):596-603 [FREE Full text] [doi: 10.1007/s11239-020-02225-1] [Medline: 32661758]

37. Tulius Silva M, Quintanilha G, Giesel L, Beatriz Soldati A, Jabarra C, Almeida C, et al. The impact of the COVID-19 pandemic on a stroke center in Latin America. Int J Stroke 2020 Oct;15(7):813-814. [doi: 10.1177/1747493020941637] [Medline: 32589117$]$

38. Avula A, Nalleballe K, Narula N, Sapozhnikov S, Dandu V, Toom S, et al. COVID-19 presenting as stroke. Brain Behav Immun 2020 Jul;87:115-119 [FREE Full text] [doi: 10.1016/j.bbi.2020.04.077] [Medline: 32360439]

39. Mehta P, McAuley DF, Brown M, Sanchez E, Tattersall RS, Manson JJ, HLH Across Speciality Collaboration, UK. COVID-19: consider cytokine storm syndromes and immunosuppression. Lancet 2020 Mar 28;395(10229):1033-1034 [FREE Full text] [doi: 10.1016/S0140-6736(20)30628-0] [Medline: 32192578]

40. Radmanesh A, Raz E, Zan E, Derman A, Kaminetzky M. Brain Imaging Use and Findings in COVID-19: A Single Academic Center Experience in the Epicenter of Disease in the United States. AJNR Am J Neuroradiol 2020 Jul;41(7):1179-1183. [doi: 10.3174/ajnr.A6610] [Medline: 32467191]

41. Ameriso SF, Wong VL, Quismorio FP, Fisher M. Immunohematologic characteristics of infection-associated cerebral infarction. Stroke 1991 Aug;22(8):1004-1009. [doi: 10.1161/01.str.22.8.1004] [Medline: 1866745]

42. Macko RF, Ameriso SF, Gruber A, Griffin JH, Fernandez JA, Barndt R, et al. Impairments of the protein C system and fibrinolysis in infection-associated stroke. Stroke 1996 Nov;27(11):2005-2011. [doi: 10.1161/01.str.27.11.2005] [Medline: $\underline{8898806}]$

43. Chen T, Wu D, Chen H, Yan W, Yang D, Chen G, et al. Clinical characteristics of 113 deceased patients with coronavirus disease 2019: retrospective study. BMJ 2020 Mar 26;368:m1091. [doi: 10.1136/bmj.m1091] [Medline: 32217556]

44. Kansagra AP, Goyal MS, Hamilton S, Albers GW. Collateral Effect of Covid-19 on Stroke Evaluation in the United States. N Engl J Med 2020 Jul 23;383(4):400-401 [FREE Full text] [doi: 10.1056/NEJMc2014816] [Medline: 32383831]

45. Siegler JE, Heslin ME, Thau L, Smith A, Jovin TG. Falling stroke rates during COVID-19 pandemic at a comprehensive stroke center. J Stroke Cerebrovasc Dis 2020 Aug;29(8):104953 [FREE Full text] [doi: 10.1016/j.jstrokecerebrovasdis.2020.104953] [Medline: 32689621]

46. Onteddu SR, Nalleballe K, Sharma R, Brown AT. Underutilization of health care for strokes during the COVID-19 outbreak. Int J Stroke 2020 Jul;15(5):NP9-NP10. [doi: 10.1177/1747493020934362] [Medline: 32478606]

47. Pandey AS, Daou BJ, Tsai JP, Zaidi SF, Salahuddin H, Gemmete JJ, Michigan Stroke Treatment Improvement Collaborative (MISTIC). Letter: COVID-19 Pandemic-The Bystander Effect on Stroke Care in Michigan. Neurosurgery 2020 Sep 01;87(3):E397-E399 [FREE Full text] [doi: 10.1093/neuros/nyaa252] [Medline: $\underline{\text { 32496518] }}$

48. Sweid A, Jabbour P, Tjoumakaris S. Letter to the Editor: Incidence of Acute Ischemic Stroke and Rate of Mechanical Thrombectomy During the COVID-19 Pandemic in a Large Tertiary Care Telemedicine Network. World Neurosurg 2020 Aug;140:491-492 [FREE Full text] [doi: 10.1016/j.wneu.2020.06.053] [Medline: 32544621]

49. Uchino K, Kolikonda MK, Brown D, Kovi S, Collins D, Khawaja Z, et al. Decline in Stroke Presentations During COVID-19 Surge. Stroke 2020 Aug;51(8):2544-2547 [FREE Full text] [doi: 10.1161/STROKEAHA.120.030331] [Medline: 32716818 ]

50. Nguyen-Huynh MN, Tang XN, Vinson DR, Flint AC, Alexander JG, Meighan M, et al. Acute Stroke Presentation, Care, and Outcomes in Community Hospitals in Northern California During the COVID-19 Pandemic. Stroke 2020 Aug 07;51(10):2918-2924 [FREE Full text] [doi: 10.1161/STROKEAHA.120.031099] [Medline: 32762619]

51. Rinkel LA, Prick JCM, Slot RER, Sombroek NMA, Burggraaff J, Groot AE, et al. Impact of the COVID-19 outbreak on acute stroke care. J Neurol 2020 Jul 20 [FREE Full text] [doi: 10.1007/s00415-020-10069-1] [Medline: 32691235] 
52. Jasne AS, Chojecka P, Maran I, Mageid R, Eldokmak M, Zhang Q, et al. Stroke Code Presentations, Interventions, and Outcomes Before and During the COVID-19 Pandemic. Stroke 2020 Sep;51(9):2664-2673 [FREE Full text] [doi: 10.1161/STR.0000000000000347] [Medline: $\underline{\text { 32755347] }}$

53. July J, Pranata R. Impact of the Coronavirus Disease Pandemic on the Number of Strokes and Mechanical Thrombectomies: A Systematic Review and Meta-Analysis. J Stroke Cerebrovasc Dis 2020 Nov;29(11):105185. [doi:

10.1016/j.jstrokecerebrovasdis.2020.105185]

54. Hartnett KP, Kite-Powell A, DeVies J, Coletta MA, Boehmer TK, Adjemian J, National Syndromic Surveillance Program Community of Practice. Impact of the COVID-19 Pandemic on Emergency Department Visits - United States, January 1, 2019-May 30, 2020. MMWR Morb Mortal Wkly Rep 2020 Jun 12;69(23):699-704 [FREE Full text] [doi: 10.15585/mmwr.mm6923e1] [Medline: 32525856]

55. Lange SJ, Ritchey MD, Goodman AB, Dias T, Twentyman E, Fuld J, et al. Potential Indirect Effects of the COVID-19 Pandemic on Use of Emergency Departments for Acute Life-Threatening Conditions - United States, January-May 2020. MMWR Morb Mortal Wkly Rep 2020 Jun 26;69(25):795-800 [FREE Full text] [doi: 10.15585/mmwr.mm6925e2] [Medline: 32584802]

56. Zhao J, Li H, Kung D, Fisher M, Shen Y, Liu R. Impact of the COVID-19 Epidemic on Stroke Care and Potential Solutions. Stroke 2020 Jul;51(7):1996-2001 [FREE Full text] [doi: 10.1161/STROKEAHA.120.030225] [Medline: 32432997]

57. Schlachetzki F, Theek C, Hubert ND, Kilic M, Haberl RL, Linker RA, et al. Low stroke incidence in the TEMPiS telestroke network during COVID-19 pandemic - effect of lockdown on thrombolysis and thrombectomy. J Telemed Telecare 2020 Aug 18:1357633X20943327. [doi: 10.1177/1357633X20943327] [Medline: 32811274]

58. Schirmer CM, Ringer AJ, Arthur AS, Binning MJ, Fox WC, James RF, Endovascular Research Group (ENRG). Delayed presentation of acute ischemic strokes during the COVID-19 crisis. J Neurointerv Surg 2020 Jul;12(7):639-642 [FREE Full text] [doi: 10.1136/neurintsurg-2020-016299] [Medline: 32467244$]$

59. Pop R, Quenardelle V, Hasiu A, Mihoc D, Sellal F, Dugay MH, et al. Impact of the COVID-19 outbreak on acute stroke pathways - insights from the Alsace region in France. Eur J Neurol 2020 May 12 [FREE Full text] [doi: 10.1111/ene.14316] [Medline: 32399995]

60. Hecht N, Wessels L, Werft F, Schneider UC, Czabanka M, Vajkoczy P. Need for ensuring care for neuro-emergencies-lessons learned from the COVID-19 pandemic. Acta Neurochir (Wien) 2020 Aug;162(8):1795-1801 [FREE Full text] [doi: 10.1007/s00701-020-04437-z] [Medline: 32514620]

61. Yang B, Wang T, Chen J, Chen Y, Wang Y, Gao P, et al. Impact of the COVID-19 pandemic on the process and outcome of thrombectomy for acute ischemic stroke. J Neurointerv Surg 2020 Jul;12(7):664-668 [FREE Full text] [doi: 10.1136/neurintsurg-2020-016177] [Medline: 32451358]

62. Naccarato M, Scali I, Olivo S, Ajčević M, Buoite Stella A, Furlanis G, et al. Has COVID-19 played an unexpected "stroke" on the chain of survival? J Neurol Sci 2020 Jul 15;414:116889 [FREE Full text] [doi: 10.1016/j.jns.2020.116889] [Medline: 32416370]

63. Teo K, Leung WCY, Wong Y, Liu RKC, Chan AHY, Choi OMY, et al. Delays in Stroke Onset to Hospital Arrival Time During COVID-19. Stroke 2020 Jul;51(7):2228-2231 [FREE Full text] [doi: 10.1161/STROKEAHA.120.030105] [Medline: 32432998]

64. Kerleroux B, Fabacher T, Bricout N, Moïse M, Testud B, Vingadassalom S, SFNR, the ETIS registry, the JENI-Research Collaborative. Mechanical Thrombectomy for Acute Ischemic Stroke Amid the COVID-19 Outbreak: Decreased Activity, and Increased Care Delays. Stroke 2020 Jul;51(7):2012-2017. [doi: 10.1161/STROKEAHA.120.030373] [Medline: 32432994]

65. Cummings C, Almallouhi E, Al Kasab S, Spiotta AM, Holmstedt CA. Blacks Are Less Likely to Present With Strokes During the COVID-19 Pandemic: Observations From the Buckle of the Stroke Belt. Stroke 2020 Aug 05;51(10):3107-3111 [FREE Full text] [doi: 10.1161/STROKEAHA.120.031121] [Medline: 32755454]

66. Escalard S, Chalumeau V, Escalard C, Redjem H, Delvoye F, Hébert S, et al. Early Brain Imaging Shows Increased Severity of Acute Ischemic Strokes With Large Vessel Occlusion in COVID-19 Patients. Stroke 2020 Aug 19:STROKEAHA120031011 [FREE Full text] [doi: 10.1161/STROKEAHA.120.031011] [Medline: 32813602]

67. Grau AJ, Urbanek C, Palm F. Common infections and the risk of stroke. Nat Rev Neurol 2010 Dec;6(12):681-694. [doi: 10.1038/nrneurol.2010.163] [Medline: 21060340]

68. Pagliano P, Spera AM, Ascione T, Esposito S. Infections causing stroke or stroke-like syndromes. Infection 2020 Jun;48(3):323-332. [doi: 10.1007/s15010-020-01415-6] [Medline: 32239441]

69. Stokes EK, Zambrano LD, Anderson KN, Marder EP, Raz KM, El Burai Felix S, et al. Coronavirus Disease 2019 Case Surveillance - United States, January 22-May 30, 2020. MMWR Morb Mortal Wkly Rep 2020 Jun 19;69(24):759-765 [FREE Full text] [doi: 10.15585/mmwr.mm6924e2] [Medline: 32555134]

70. Killerby ME, Link-Gelles R, Haight SC, Schrodt CA, England L, Gomes DJ, CDC COVID-19 Response Clinical Team. Characteristics Associated with Hospitalization Among Patients with COVID-19 - Metropolitan Atlanta, Georgia, March-April 2020. MMWR Morb Mortal Wkly Rep 2020 Jun 26;69(25):790-794 [FREE Full text] [doi: 10.15585/mmwr.mm6925e1] [Medline: 32584797] 
71. Gold JAW, Wong KK, Szablewski CM, Patel PR, Rossow J, da Silva J, et al. Characteristics and Clinical Outcomes of Adult Patients Hospitalized with COVID-19 - Georgia, March 2020. MMWR Morb Mortal Wkly Rep 2020 May 08;69(18):545-550 [FREE Full text] [doi: 10.15585/mmwr.mm6918e1] [Medline: 32379729]

72. Price-Haywood EG, Burton J, Fort D, Seoane L. Hospitalization and Mortality among Black Patients and White Patients with Covid-19. N Engl J Med 2020 Jun 25;382(26):2534-2543 [FREE Full text] [doi: 10.1056/NEJMsa2011686] [Medline: $\underline{32459916}$

73. Millett GA, Jones AT, Benkeser D, Baral S, Mercer L, Beyrer C, et al. Assessing differential impacts of COVID-19 on black communities. Ann Epidemiol 2020 Jul;47:37-44 [FREE Full text] [doi: 10.1016/j.annepidem.2020.05.003] [Medline: $\underline{32419766]}$

74. Yehia BR, Winegar A, Fogel R, Fakih M, Ottenbacher A, Jesser C, et al. Association of Race With Mortality Among Patients Hospitalized With Coronavirus Disease 2019 (COVID-19) at 92 US Hospitals. JAMA Netw Open 2020 Aug 03;3(8):e2018039 [FREE Full text] [doi: 10.1001/jamanetworkopen.2020.18039] [Medline: 32809033]

75. Yancy CW. COVID-19 and African Americans. JAMA 2020 May 19;323(19):1891-1892. [doi: 10.1001/jama.2020.6548] [Medline: $\underline{32293639]}$

76. Rodriguez-Diaz CE, Guilamo-Ramos V, Mena L, Hall E, Honermann B, Crowley JS, et al. Risk for COVID-19 infection and death among Latinos in the United States: examining heterogeneity in transmission dynamics. Ann Epidemiol 2020 Jul 23 [FREE Full text] [doi: 10.1016/j.annepidem.2020.07.007] [Medline: 32711053]

77. Sáenz R, Garcia MA. The Disproportionate Impact of COVID-19 on Older Latino Mortality: The Rapidly Diminishing Latino Paradox. J Gerontol B Psychol Sci Soc Sci 2020 Sep 08. [doi: 10.1093/geronb/gbaa158] [Medline: 32898235]

78. Menachemi N, Yiannoutsos CT, Dixon BE, Duszynski TJ, Fadel WF, Wools-Kaloustian KK, et al. Population Point Prevalence of SARS-CoV-2 Infection Based on a Statewide Random Sample - Indiana, April 25-29, 2020. MMWR Morb Mortal Wkly Rep 2020 Jul 24;69(29):960-964 [FREE Full text] [doi: 10.15585/mmwr.mm6929e1] [Medline: 32701938 ]

79. Ghanchi H, Patchana T, Wiginton J, Browne JD, Ohno A, Farahmandian R, et al. Racial Disparity Amongst Stroke Patients During the Coronavirus Disease 2019 Pandemic. Cureus 2020 Sep 10;12(9):e10369. [doi: 10.7759/cureus.10369]

80. Swerdel JN, Janevic TM, Cosgrove NM, Kostis JB, Myocardial Infarction Data Acquisition System (MIDAS 24) Study Group. The effect of Hurricane Sandy on cardiovascular events in New Jersey. J Am Heart Assoc 2014 Dec 08;3(6):e001354. [doi: 10.1161/JAHA.114.001354] [Medline: 25488295]

81. Nakamura A, Nozaki E, Fukui S, Endo H, Takahashi T, Tamaki K. Increased risk of acute myocardial infarction after the Great East Japan Earthquake. Heart Vessels 2014 Mar;29(2):206-212. [doi: 10.1007/s00380-013-0353-y] [Medline: 23604314]

82. Huang H, Yen DH, Kao W, Wang L, Huang C, Lee C. Declining emergency department visits and costs during the severe acute respiratory syndrome (SARS) outbreak. J Formos Med Assoc 2006 Jan;105(1):31-37 [FREE Full text] [doi: 10.1016/S0929-6646(09)60106-6] [Medline: 16440068]

83. Lee SY, Khang YH, Lim HK. Impact of the 2015 Middle East Respiratory Syndrome Outbreak on Emergency Care Utilization and Mortality in South Korea. Yonsei Med J 2019 Aug;60(8):796-803 [FREE Full text] [doi: 10.3349/ymj.2019.60.8.796] [Medline: $\underline{31347336]}$

\author{
Abbreviations \\ AHA/ASA: American Heart Association/American Stroke Association \\ DNV-GL: Det Norske Veritas Germanischer Lloyd \\ ED: emergency department \\ EMS: emergency medical services \\ EVT: endovascular therapy \\ GWTG: Get With The Guidelines \\ ICU: intensive care unit \\ LVO: large vessel occlusion \\ MERS: Middle East respiratory syndrome \\ NIHSS: National Institutes of Health Stroke Scale \\ SARS: severe acute respiratory syndrome \\ TIA: transient ischemic attack \\ TLKW: time last known well
}


Edited by J Wang; submitted 23.06.20; peer-reviewed by S Levine, KA Nguyen; comments to author 26.08.20; revised version received 18.09.20; accepted 27.09.20; published 21.10.20

Please cite as:

Dula AN, Gealogo Brown G, Aggarwal A, Clark KL

Decrease in Stroke Diagnoses During the COVID-19 Pandemic: Where Did All Our Stroke Patients Go?

JMIR Aging 2020;3(2):e21608

URL: http://aging.jmir.org/2020/2/e21608/

doi: $10.2196 / 21608$

PMID: $\underline{3006936}$

(C)Adrienne Nicole Dula, Gretchel Gealogo Brown, Aarushi Aggarwal, Kal L Clark. Originally published in JMIR Aging (http://aging.jmir.org), 21.10.2020. This is an open-access article distributed under the terms of the Creative Commons Attribution License (https://creativecommons.org/licenses/by/4.0/), which permits unrestricted use, distribution, and reproduction in any medium, provided the original work, first published in JMIR Aging, is properly cited. The complete bibliographic information, a link to the original publication on http://aging.jmir.org, as well as this copyright and license information must be included. 